\title{
Reconciliation of Humanitarian Law and Human Rights Law in Armed Conflict
}

\author{
Muhammad Ashri \\ Faculty of Law, Hasanuddin University, Indonesia. \\ E-mail:muhammad.ashri@unhas.ac.id
}

\begin{tabular}{l} 
ARTICLE INFO \\
\hline Keywords: \\
Armed Conflict; Human \\
Rights; Humanitarian Law; \\
International Law \\
How to cite: \\
Ashri, M. (2019). \\
"Reconciliation of \\
Humanitarian Law and \\
Human Rights Law in \\
Armed Conflict" \\
Hasanuddin Law Review, \\
5(2): 209-219 \\
DOI: \\
10.20956/halrev.v5i2.1348
\end{tabular}

\section{Introduction}

The relation of International Humanitarian Law (IHL) and International Human Rights Law (IHRL) becomes an interesting topic to be studied, especially for academics, governments, and activists of international organizations. Both international humanitarian law and international human rights law strive to protect the lives, health and dignity of individuals, albeit from a different angle. ${ }^{1}$ The complexity of the problems related to the topic becomes a debate when it is associated with the application of

1 ICRC. (2003). International Humanitarian Law and International Human Rights Law: Similarities and differences. Advisory Service on International Humanitarian Law. Available online at: https://www.icrc.org/en/doc/assets/files/other/ihl_and_ihrl.pdf 
international humanitarian law and human rights law norms in various conflicts that have occurred lately. ${ }^{2}$

International humanitarian law and human rights law are closely related in the development of international law. The relation between the two concepts is obtained by finding a special pattern both from a theoretical aspect and in the perspective of its application. International humanitarian law and human rights law are seen as a unit and be a part of public international law. Both instruments were established in order to protect human rights and dignity.

A common view interprets human rights law as a legal instrument that is applied to peace and conflict conditions, while international humanitarian law is applied when armed conflict occurs. ${ }^{3}$ Overlap between the two legal instruments occurs in a conflict situation. This paper seeks to explain how the relationship of international humanitarian law and human rights law as related to the overlap of two legal instruments in conflict situations. Whether the international humanitarian law as a special international legal instrument "lex specialist" can exclude human rights law in conditions of armed conflict?

At the beginning, this paper discussed the concepts and relation of both through international law. Furthermore, it is explained how the similarities between the two elements in general, following several differentiators, include time; scope; subject and nature. In discussions on the application of international humanitarian law and human rights law, we discuss the international subjects and case examples in linking the implementation concept of both.

\section{International Humanitarian Law and Human Rights Law}

In a theoretical perspective, the relationship of international humanitarian law and human rights law can be explained through 3 (three) thought, namely integrationist, separatist, and complementary. ${ }^{4}$

\subsection{Integrationist thought}

According to this thought that the existence of a legal system comes from other laws, so there are 2 (two) possibilities; first, the presence of the International Humanitarian Law is based on human rights; thus the humanitarian law is a branch of Human Rights Law. Robertson considers that "... the law regarding human rights must be seen as a law that covers several other branches of law, in which the humanitarian war law is a particular part $^{5}$. Thus it can be said that Human Rights Law is a genus and humanitarian law as its species.

This is supported by the argument that the application of humanitarian law is only in armed conflict situation, whereas Human Rights Law applies both in peace or armed conflict situation. Second, the International Humanitarian Law becomes a basis of Human Rights Law in the sense that Human Rights Law is part of the International

\footnotetext{
2 Russell A. Miller and Rebecca Bratspies (ed) (2009) Progress in International Law, Netherland: Koninklijke Brill NV, p. 692.

${ }^{3}$ Antônio Augusto Cançado Trindade. (2010). International Law for Humankind: Towards a New Jus Gentium. Leiden: Martinus Nijhoff Publ. \& VSP, p. 515.

4 Permanasari, A., Wibowo, A., Agus, F., and Romsan, A. (1999). Pengantar Hukum Humaniter. Jakarta: ICRC, pp. 337-339.

5 Peter Baehr et al. (2001). Instrumen Internasional Pokok Hak-Hak Asasi Manusia. Jakarta: Yayasan Obor Indonesia, p. 3.
} 
Humanitarian Law. Such opinions were developed among others by Jean Pictet and followed by P. van Dijk who argued that Humanitarian Law in a broad sense includes the Humanitarian War Law, humanitarian law to maintain peace, and international law on human rights. ${ }^{6}$ This opinion is also supported by the fact that the International Humanitarian Law was established earlier than Human Rights Law or chronologically the Human Rights Law was developed after the International Humanitarian Law.

\subsection{Separatist thought}

This thought views that the International Humanitarian Law and Human Rights Law are two distinct legal systems. This position is followed by G.I.A.D Draper. Draper stated that the International Humanitarian Law and Human Rights Law "...not only distinct but are diametrically opposed."7

\subsection{Complementary thought}

This thought views that the International Humanitarian Law and Human Rights Law through a process that is gradually developing in parallel and complementary. ${ }^{8}$ This position is followed by Yutaka Arai-Takahashi. ${ }^{9}$ They recognize that International Humanitarian Law and Human Rights Law are two distinct legal fields, although this thought does not prioritize differences but prioritizes equality because both fields of law have the same goal. All the elements together are then used to complement each other in order to achieve the same goal, namely protecting individuals. As thoughts described above, we can identify the similarities and dissimilarities between the International Humanitarian Law and Human Rights Law.

\section{Similarities in International Humanitarian Law and Human Rights Law}

International Humanitarian Law and Human Rights Law is part of public international law. These two branches of law regulate behavior to protect humans based on the same basic principle, to respect the human dignity. ${ }^{10}$ For example, the protection of individual in the context of international humanitarian law is found in Article 3 of the four Geneva Conventions of 1949. In that article often referred to as "concurrent rules", stated that people who do not actively participate in armed disputes under any circumstances must be treated on the basis of humanity, without any distinction that can disadvantageous based on race, religion or belief, gender, ancestry or wealth, or other similar criteria.

The principles of humanitarian as listed in Article 3 are re-affirmed in the Preamble to the Additional Protocol to the Geneva Conventions of 12 August 1949, and relating to the Protection of Victims of Non-International Armed Conflict (Protocol II). In this Preamble stated that "Recalling' furthermore that international instruments relating to human rights offer a basic protection to the human person."

6 Ibid., p. 5-7.

7 Philip Alston and Ryan Goodman. (2013). International Human Rights: Text and Materials. Oxford: Oxford University Press, p. 408.

8 For example, see Gideon Boas. (2012). Public International Law: Contemporary Principles and Perspectives UK: Edward Elgar Publ. Ltd., p. 36

9 Yutaka Arai-Takahashi, "The Interaction between International Humanitarian Law and International Human Rights Law" as cited in Anja Mihr and Mark Gibney (eds). (2014). The SAGE Handbook of Human Rights. LA: Sage, p. 93.

10 Malcolm N. Shaw. (2008). International Law. $6^{\text {th }}$ edition. Cambridge: Cambridge University Press, p. 1196; See also: Olivier De Schutter. (2010). International Human Rights Law: Cases, Materials, Commentary. Cambridge: Cambridge University Press, p. 4 


\section{Distinction of International Humanitarian Law and Human Rights Law}

\subsection{Validity time}

International Humanitarian Law has a limited validity of applicability, namely in armed conflict situation (international and non-international). Meanwhile, Human Rights Law applies in all situations, both in peaceful and armed conflict conditions.

\subsection{Scope of norms}

The International Humanitarian Law norms can be referred to as norms that have a global or universal spectrum. Almost all countries today accept the rules of International Humanitarian Law as regulated in the Geneva Conventions of 1949. However, the substance of international humanitarian law norms is limited to the regulation of instrument or means and behavior in armed conflict.

In contrast to International Humanitarian Law, Human Rights Law in addition to being regulated through global instruments is also regulated in various regional instruments, such as human rights law in Africa, America, Arabic, Europe, and Islamic Human Rights values. However, the substance of human rights law norms covers many aspects, including civil, political, economic, social and cultural rights, and also collective rights/solidarity.

\subsection{Setting subject}

As a consequence of the limited scope of regulation, then International Humanitarian Law only regulates parties involved with armed conflict, while Human Rights Law regulates relations and behavior of State or government to individuals.

\subsection{Character of norm}

The rights contained in International Humanitarian Law norms apply absolutely without exception. In contrast to that, there are certain rights that are regulated in Human Rights Law under certain conditions which can be suspended, for example in an emergency.

For example, Party States to the Covenant of Civil and Politics, in certain circumstances have the right to take steps to reduce the various obligations. This right is stated in Article 4 of the Covenant, as follows:

a. In emergency situation which threaten the life of the nation and its existence, as it has been officially announced, the Party States to the Covenant can take steps that reduce their obligations under this Covenant, as far they are indispensable in such emergency situations, and as far the steps are not conflict with other obligations under international law and does not contain discrimination based solely on race, color, gender, language, religion, or social origin;

b. Reduction of obligation for articles 6, 7, 8 paragraph (1) and (2), 11, 15, 16, and 18 cannot be justified based on this provision;

c. Every Party State to the Covenant that exercises the right to make such reductions must immediately notify the other States parties through the mediation of the Secretary-General of the United Nations, regarding the reasons for their enact. Further notice must be made through the same intermediary at the end of the reduction.

A similar clause to the Covenant above is also found in the American and European Conventions regarding Human Rights. However, differ with the two regional conventions as mentioned last, the Covenant of Civil and Politics does not list "war" or 
"armed conflict" as a reason that can suspend or reduce the State' obligation to respect and protect human rights. Travaux Preparatoires pointed out that this neglect was deliberate and motivated by concern, although it was recognized that one of the most important common emergencies was the outbreak of war, but the Covenant should not imagine, even concluded as such because the United Nations was established with the aim of preventing war. The neglection against war as a special reference is not intended to deny the existence of a reduction in rights during the war; a war is a dramatic example of a common emergencies that can threaten the life of the nation. ${ }^{11}$

\section{Application of International Humanitarian Law and Human Rights Law}

In contrast to International Humanitarian Law which only applies in situations of armed conflict, Human Rights Law applies both in peace of armed conflict situations. The application of human rights law in armed conflict was formally accepted at an international conference on human rights from 22 April-13 May 1968 in Tehran. The conference recognized that human rights law applies in armed conflicts. ${ }^{12}$

The application of human rights law especially for certain norms are absolute in the sense that the norms referred to cannot be excluded on the basis of war or armed conflict. The provisions can be found in the Conventions and Declarations as follows:

a. Convention against Torture and Other Cruel, Inhuman or Degrading Treatment or Punishment (1984)

Article 2 the Convention of Anti-Torture mentioned above, states that there are no exceptions in any case whether in a war or threat of war which can be used as reason to do torture.

Article 2

(1) Each State Party shall take effective legislative, administrative, judicial or other measures to prevent acts of torture in any territory under its jurisdiction.

(2) No exceptional circumstances whatsoever, whether a state of war or a threat of war, internal political instability or any other public emergency, may be invoked as a justification of torture. 13

b. Convention on the Rights of the Child (1989)

Article 39 the Convention on the Rights of the Child (1989) contains commitments to promote the recovery and reintegration of children victims of war and to prohibit the recruitment and abuse of child soldiers. ${ }^{14}$

Article 39

States Parties shall take all appropriate measures to promote physical and psychological recovery and social reintegration of a child victim of: any form of neglect, exploitation, or abuse; torture or any other form of cruel, inhuman or degrading treatment or punishment; or armed conflicts. Such recovery and reintegration shall take place in an environment which fosters the health, self-respect and dignity of the child.

11 Ifdhal Kasim (ed). (2001). Hak-Hak Sipil dan Politik: Esai-esai Pilihan. Jakarta: ELSAM, pp. 328-329.

12 See MU-UN Resolution No. 2675 (XXV) "Respect for human rights in armed conflicts" Para. 9 point 1: "Fundamental human rights as accepted in international law and laid down in international instruments, continue to apply fully in situations of armed conflict."

13 Convention against Torture and Other Cruel, Inhuman or Degrading Treatment or Punishment (1984), Adopted and opened for signature, ratification and accession by the General Assembly, resolution 39/46, A/RES/39/46, 10 December 1984

14 Convention on the Rights of the Child (1989), Adopted and opened for signature, ratification and accession by the General Assembly, resolution 44/25, A/RES/44/25, 20 November 1989 
c. United Nations Declaration on the Rights of Indigenous Peoples (2007) Article 30 the declaration of the rights of Indigenous people received by the UNs Human Rights Council in 2006 stipulates restrictions on military activities on the lands and territories of indigenous people, ${ }^{15}$ as follows:

Article 30

(1) Military activities shall not take place in the lands or territories of indigenous peoples, unless justified by a relevant public interest or otherwise freely agreed with or requested by the indigenous peoples concerned.

(2) States shall undertake effective consultations with the indigenous peoples concerned, through appropriate procedures and in particular through their representative institutions, prior to using their lands or territories for military activities.

The provisions in several instrument of global human rights law as mentioned above expressly state the enactment of human rights law norms without excluding the situation of war or armed conflict. However, the instrument of regional human rights law state otherwise; enforce human rights norms except in situations of war or armed conflict, as cited in the following instruments.

a. European Convention for the Protection of Human Rights and Fundamental Freedoms ${ }^{16}$

Article 15: Derogation in time of emergency

(1) In time of war or other public emergency threatening the life of the nation any High Contracting Party may take measures derogating from its obligations under this Convention to the extent strictly required by the exigencies of the situation, provided that such measures are not inconsistent with its other obligations under international law

b. American Convention on Human Rights "Pact of San José, Costa Rica" (1969)17

Article 27: Suspension of Guarantees

(1) In time of war, public danger, or other emergency that threatens the independence or security of a State Party, it may take measures derogating from its obligations under the present Convention to the extent and for the period of time strictly required by the exigencies of the situation, provided that such measures are not inconsistent with its other obligations under international law and do not involve discrimination on the ground of race, color, sex, language, religion, or social origin.

(2) The foregoing provision does not authorize any suspension of the following articles: Article 3 (Right to Juridical Personality), Article 4 (Right to Life), Article 5 (Right to Humane Treatment), Article 6 (Freedom from Slavery), Article 9 (Freedom from Ex Post Facto Laws), Article 12 (Freedom of Conscience and Religion), Article 17 (Rights of the Family), Article 18 (Right to a Name), Article 19 (Rights of the Child), Article 20 (Right to Nationality), and Article 23 (Right to Participate in Government), or of the judicial guarantees essential for the protection of such rights.

In this regard, International Humanitarian Law tends to apply the values of Human Rights Law to armed conflict situation within the framework of the Geneva Convention. A general provision related to human rights law is Article 3 of the concurrent rules, in

15 United Nations Declaration on the Rights of Indigenous Peoples (2007), Adopted by the General Assembly, A/61/L.67 and Add.1, 13 September 2007

16 Council of Europe, European Convention for the Protection of Human Rights and Fundamental Freedoms, as amended by Protocols Nos. 11 and 14, 4 November 1950, ETS 5, available at: http://www.refworld.org/docid/3ae6b3b04.html <last visited, 17 May 2019>.

17 American Convention on Human Rights "Pact of San José, Costa Rica" (1969), Adopted at an InterAmerican Specialized Conference on Human Rights, San José, Costa Rica, 22 November 1969 
addition to the Additional Protocol of the 1977 Geneva Convention (Article 72 of Protocol I).

Philip Alston and Ryan Goodman wrote that a number of observers and a little of countries, including the United States stated that under certain conditions, namely in armed conflict situation, the International Humanitarian Law would replace the enactment of Human Rights Law. Several countries including the Netherlands and England stated that International Humanitarian Law is intended to protect parties in situations of armed conflict. Therefore, if there is a death that arises as a result of the conflict, it must be placed within the framework of International Humanitarian Law and not be seen as an act of "revoking the right to life" as stipulated in the Covenant of Civil and Politics." 18

\subsection{International Court of Justice (ICJ)}

Related to this regard, ICJ makes a very influential statement, especially in "The Legality of the Threat or Use of Nuclear Weapons." ICJ makes a seemingly contradictory argument, one opinion stating that possessing, threatening or using nuclear weapons violates the right to life under the Covenant of Civil and Politics. While, on the other hand it was stated that the Covenant of Civil and Politics only protects human rights in a peaceful state.

In a statement always cited, the ICJ states that the protection as regulated in the Covenant of Civil and Politics does not stop in situations of war, unless it relates to Article 4 of the Covenant. In principle, "a person's right not to be deprived of his/her life" also applies in war situation. The touchstone to state whether there is "deprivation of the right to life" is determined based on the applicable law in armed conflict as a specific law governing behavior in war.

\section{The Court observes that the protection of the International Covenant of Civil and Political Rights does not cease in times of war, except by operation of Article 4 of the Covenant whereby certain provisions may be derogated from in a time of national emergency. Respect for the right to life is not, however, such a provision. In principle, the right not arbitrarily to be deprived of one's life applies also in hostilities. The test of what is an arbitrary deprivation of life, however, then falls to be determined by the applicable lex specialis, namely, the law applicable in armed conflict which is designed to regulate the conduct of hostilities. Thus whether a particular loss of life, through the use of a certain weapon in warfare, is to be considered an arbitrary deprivation of life contrary to Article 6 of the Covenant, can only be decided by reference to the law applicable in armed conflict and not deduced from the terms of the Covenant itself. ${ }^{19}$}

Then, ICJ raised two opinions regarding the application of human rights law in armed conflict and military occupation. The first, in 2004 related to the construction of Israel separation wall in Palestinian territories, ${ }^{20}$ and the second in 2006 related to the armed conflict between the Democratic Republic of Congo and Uganda. In the latter case, ICJ restated that human rights law instruments remain relevant to the actions of a country that exercises jurisdiction outside its territory, particularly in occupied territories. Then, the ICJ concluded that in this case, Uganda was internationally responsible for various

18 Philip Alston and Ryan Goodman, Op. Cit, p. 409 25.

19 Legality of the Threat or Use of Nuclear Weapons, Advisory opinion, I.C.J. Reports 1996 p. 240, para.

20 Legal Consequences of the Construction of a Wall in the Occupied Palestinian Territory, Advisory Opinion, reproduced in document A/ES-10/273 and Corr.1 
violations of human rights law and international humanitarian law, including violations committed because they did not fulfill their obligations as the state occupying the disputed territory.

In this case, the ICJ stated that Uganda clearly violated its international obligations based on:

a. The Hague Regulations 1907, articles 25, 27 and 28, 43, 46 and 47 relating to the obligations of the parties occupying a territory;

b. Geneva Convention IV, articles 27 and 32, article 53 relating to the obligations of the parties occupying a territory;

c. The Covenant of Civil and Politics, articles 6, paragraphs 1 and 7; Protocol I of the Geneva Conventions, articles 48, 51, 52, 57, 58 and 75, paragraphs 1 and 2;

d. African Charter on Human and Peoples' Rights, articles 4 and 5;

e. Convention on the Rights of the Child, article 38, paragraphs 2 and 3;

f. Additional Protocols to the Convention on the Rights of the Child, articles 1, 2, 3, paragraphs $3,4,5$ and 6 .

The protection of human rights continues to apply in situations of armed conflict. The relationship between international humanitarian law and human rights law can give rise to three conditions, namely: certain specific rights are exclusively subject to the international humanitarian law regime; the other is exclusively subject to the human rights law regime and the others are in the two branches of international law. ${ }^{21}$

Meanwhile, the International Criminal Court (ICC) based on the "Rome Statute" Article 21 para. (1) and (3), will adjudicate its case based on the statutes, ICCs Provisions and Procedures as main reference and when necessary the ICC will apply the principle and international legal norms, including the principles of international humanitarian law. However, the application and interpretation of norms and facts encountered must be in accordance with internationally recognized human rights law.

\subsection{International Committee of the Red Cross (ICRC)}

In 2003, the ICRC held a meeting attended by 200 participants of IGO and NGO, concludes that in situations of armed conflict, international humanitarian law and human rights law apply, at least "core" provisions to complement international humanitarian law. ${ }^{22}$ Main provisions also referred to as hard-core rights include: (a) the right to life; (b) prohibition of torture and other inhumane treatment; (c) prohibition of slavery; and (d) prohibition of retroactively applying criminal law. ${ }^{23}$

Also, the forum stated that international humanitarian law is a "special law" that is intended to apply when armed conflict. Some participants argued that the right to life cannot be generalized to all situations both regulated by international humanitarian law and human rights law. Conversely, if human rights law is clearer than international humanitarian law, then human rights law must be first. For example, Article 3 para. 1 (d), the concurrent provisions in the Geneva Conventions expressly refer to the

21 See: Armed Activities on the Territory of the Congo (Democratic Republic of the Congo v. Uganda), Judgment, I.C.J. Reports 2005, p. 168 para 216

22 Summary report Prepared by the International Committee of the Red Cross, Supplement to the report prepared by the International Committee of the Red Cross entitled "International Humanitarian Law and the Challenges of Contemporary Armed Conflicts" as cited on the website https://www.icrc.org/eng/assets/files/other/interplay_other_regimes_nov_2003.pdf

23 Compare to Soraya, Y.M.S. (2006). “Perlindungan Tahanan pada Kamp-kamp Penahanan Amerika Serikat", Indonesian Journal of International Law, 4 (1): 113-123 
recognition of legal guarantees that cannot be excluded for civilized society, but what is meant by civilized society is placed in the construction of thought which refers to human rights law. Debates that arose between participants to broaden the applying of international humanitarian law in addition to human rights law did not reach agreement. Some experts states that only non-derogable rights in human rights law apply in this case and any approach that will expand the application of human rights law has no legal basis.

\subsection{International Law Commission (ILC)}

In 2002, ILC published a research report on the fragmentation of international law as a result of a study group chaired by Koskenniemi who published her report in 2006.24 It was stated that what is meant by lex specialis in the legality of testing and the use of nuclear weapons (1996)? In that case, ICJ assessed that between the human rights law in this case the Covenant of Civil and Politics and the international humanitarian law, both of which apply in a war situation. However, to determine what is meant by "arbitrary deprivation of the right to life" in article 6 paragraph (1) of the Covenant of Civil and Politics, it is determined based on the application of lex specialis, a law applied in armed conflict. In this relation, the two legal fields apply simultaneously or one of them is covered by the other rules.

International humanitarian law as lex specialis does not rule out human rights law in armed conflicts. It shows that ICJs reasoning on the one hand tends to be pragmatic while on the other hand it is very idealistic.

\subsection{Guantanamo Prisoner}

Post-attack 11 September and the UNs Security Council approved the right of selfdefense for the US. The US and UK then invaded Afghanistan on October 7, 2001. In January 2002, the US began to detain and bring detained Taliban and Al-Qaeda members to a military base in Guantanamo bay, Cuba. Al-Qaeda members were not only from Afghanistan but also other countries, such as Bosnia Herzegovina, Egypt, Gambia, Mauritania, Pakistan and Thailand. Initially, the US argues that all members of the Taliban and Al-Qaeda were "illegal combatants." Therefore, they could not be classified as prisoners of war under the $3^{\text {rd }}$ Geneva Convention. Some NGOs and IGOs have different opinions from the US, including the ICRC. 25

In early 2002, a coalition of civil society filed a lawsuit to the Inter-American Human Rights Commission, they state that the US violated the American Declaration on Human Rights and Obligations, where it was recognized that the procedure as provided for in the $3^{\text {rd }}$ Geneva Convention applies in the event that a person is detained without access to the court.

\subsection{A Case of the Construction of Israeli Wall26}

In the case of the Israeli wall in the occupied Palestinian territory on July 9, 2004, the ICJ stated that the construction of the wall was a violation of international law because the Palestinian people have the right to move as guaranteed by the human rights law, in this case ICCPR, ICESCR, and CRC. The construction of the wall also violates international

24 See: ILC, Fragmentation of International Law: Difficulties Arising From The Diversification And Expansion Of International Law, Report of the Study Group of the ILC. Finalized by Martti Koskenniemi, 2006.

25 Philip Alston and Ryan Goodman, Op. Cit, pp. 415-416.

26 Wulan Kristianti. (2010). "Interrelation between Human Rights and International Humanitarian Law According to Separation Wall Case (ICJ Advisory Opinion 2004)", Indonesian Journal of International Law, 6(3): 535-541. 
humanitarian law as regulated in the Geneva Conventions (IV) 1949, as well as several DK-UN Resolutions. ${ }^{27}$

\subsection{Israel Military Operations in Gaza, 27 December 2008 - 18 January 2009}

On 3 April 2009, the UNs Human Rights Council established a Fact Finding Mission for Gaza conflict in the context of the Israeli Military Operations in the territory, 27 December 2008 - 18 January 2009. The mission conduct its duties based on a mandate covering all violations of international humanitarian law and human rights law. In the Mission Report, various findings were made that Israeli military operations in the territory violated international legal obligations, both international humanitarian law and human rights law. 28

\section{Conclusion}

Human Rights Law and International Humanitarian Law have a similar goal to guarantee human protection. Although the two branches of international law have differences in terms of time or applicability. Human Rights Law applies to peaceful and conflict situation, whereas the International Humanitarian Law only applies to armed conflict situation. In term of application, overlapping of applicable regulations (norm conflicts) can occur, especially in situations of armed conflict. The scope of application of human rights law, which includes a peace and conflict situation on the one hand and the international humanitarian law on the other hand, applies only in armed conflict situation, become a reason to state that in armed conflict situation, human rights law becomes lex generalis, whereas international humanitarian law become lex specialis.

The position of International Humanitarian Law as lex specialis at the time or armed conflict situation cannot be interpreted broadly in the sense that when the situation can be qualified as an armed conflict, only international humanitarian law applies and human rights law is ruled out. In several cases of armed conflict, the two branches of international law were applied. Thus, human rights law is applied in the event that there are facts or incidents in armed conflict that are contrary to human values, while the facts or events are not clearly regulated in international humanitarian law.

\section{References}

Anja Mihr and Mark Gibney (eds). (2014). The SAGE Handbook of Human Rights. LA: Sage. Antônio Augusto Cançado Trindade. (2010). International Law for Humankind: Towards a New Jus Gentium. Leiden: Martinus Nijhoff Publ. \& VSP.

Armed Activities on the Territory of the Congo (Democratic Republic of the Congo v. Uganda), Judgment, I.C.J. Reports 2005.

Convention against Torture and Other Cruel, Inhuman or Degrading Treatment or Punishment (1984), Adopted and opened for signature, ratification and accession by the General Assembly, resolution 39/46, A/RES/39/46.

Convention on the Rights of the Child (1989), Adopted and opened for signature, ratification and accession by the General Assembly, resolution 44/25, A/RES/44/25.

27 See: International Court of Justice, Legal Consequences of the Construction of a Wall in the Occupied Palestinian Territory, Advisory Opinion (9 July 2004), I.C.J. Reports 2004, 136, paras. 107-13

28 The Fact Finding Team of the UN, Goldstone Report: Pelanggaran HAM di Palestina (Human Rights in Palestine and Other Accupied Arab Territories). (Translated: HRWG and Dompet Dhuafa, Jakarta: Dompet Dhuafa, 2011). 
Council of Europe, European Convention for the Protection of Human Rights and Fundamental Freedoms, as amended by Protocols Nos. 11 and 14, 4 November

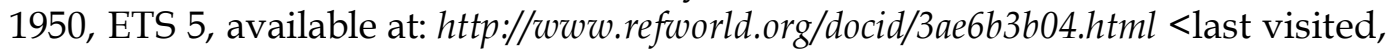
17 May 2019>.

Gideon Boas. (2012). Public International Law: Contemporary Principles and Perspectives UK: Edward Elgar Publ. Ltd.

ICRC. (2003). International Humanitarian Law and International Human Rights Law: Similarities and differences. Advisory Service on International Humanitarian Law. Available online at: $h \mathrm{ttps} / / / w w w . i c r c . o r g / e n / d o c / a s s e t s / f i l e s / o t h e r / i h l$ and_ihrl.pdf

Ifdhal Kasim (ed). (2001). Hak-Hak Sipil dan Politik: Esai-esai Pilihan. Jakarta: ELSAM.

ILC, Fragmentation of International Law: Difficulties Arising From The Diversification And Expansion Of International Law, Report of the Study Group of the ILC.

International Committee of the Red Cross, Supplement to the report prepared by the International Committee of the Red Cross entitled "International Humanitarian Law and the Challenges of Contemporary Armed Conflicts" website: https://www.icrc.org/eng/assets/files/other/interplay_other_regimes_nov_2003.pdf

International Court of Justice, Legal Consequences of the Construction of a Wall in the Occupied Palestinian Territory, Advisory Opinion (9 July 2004), I.C.J. Reports 2004.

Legality of the Threat or Use of Nuclear Weapons, Advisory opinion, I.C.J. Reports 1996.

Malcolm N. Shaw. (2008). International Law. $6^{\text {th }}$ edition. Cambridge: Cambridge University Press.

Olivier De Schutter. (2010). International Human Rights Law: Cases, Materials, Commentary. Cambridge: Cambridge University Press.

Permanasari, A., Wibowo, A., Agus, F., and Romsan, A. (1999). Pengantar Hukum Humaniter. Jakarta: ICRC.

Peter Baehr et al. (2001). Instrumen Internasional Pokok Hak-Hak Asasi Manusia. Jakarta: Yayasan Obor Indonesia.

Philip Alston and Ryan Goodman. (2013). International Human Rights: Text and Materials. Oxford: Oxford University Press.

Russell A. Miller and Rebecca Bratspies (ed) (2009) Progress in International Law, Netherland: Koninklijke Brill NV.

Soraya, Y.M.S. (2006). "Perlindungan Tahanan pada Kamp-kamp Penahanan Amerika Serikat", Indonesian Journal of International Law, 4 (1): 113-123

The Fact Finding Team of the UN, Goldstone Report: Pelanggaran HAM di Palestina (Human Rights in Palestine and Other Accupied Arab Territories). (Translated: HRWG and Dompet Dhuafa, Jakarta: Dompet Dhuafa, 2011).

United Nations Declaration on the Rights of Indigenous Peoples (2007), Adopted by the General Assembly, A/61/L.67 and Add.1, 13 September 2007

Wulan Kristianti. (2010). "Interrelation between Human Rights and International Humanitarian Law According to Separation Wall Case (ICJ Advisory Opinion 2004)", Indonesian Journal of International Law, 6(3): 535-541.

\section{Conflict of Interest Statement:}

The author(s) declares that the research was conducted in the absence of any commercial or financial relationships that could be construed as a potential conflict of interest.

Copyright (C) 2019 HALREV. All rights reserved. 